\title{
PERANCANGAN BLUEPRINT INFRASTRUKTUR JARINGAN BACKBONE KABUPATEN NGADA
}

\author{
Maria Stephani Aliandu ${ }^{(1)}$ \\ mea_aliandu@yahoo.com
}

\author{
Gani Indriyanta ${ }^{(2)}$ \\ ganind@ukdw.ac.id
}

\author{
Joko Purwadi ${ }^{(3)}$ \\ jokop@ukdw.ac.id
}

\begin{abstract}
Abstraksi
Pemerintah kabupaten Ngada telah memulai pengembangan di bidang teknologi dan informasi dengan mengadakan kerjasama dengan berbagai pihak dan telah memiliki master plan untuk kabupaten Ngada. Blueprint infrastruktur jaringan backbone menjadi salah satu bagian dalam pengembangan teknologi informasi pada kabupaten Ngada.

Jaringan yang berbasis pada teknologi wireless sebagai pengembangan dari teknologi wired dalam implementasinya memerlukan survei lapangan. Survei ini merupakan tahapan awal menentukan lokasi kandidat untuk penempatan berbagai peralatan jaringan yang mendukung pengembangan teknologi wireless. Survei ini menjadi penting ketika terdapat tantangan berupa kondisi tipografi wilayah kabupaten Ngada yang berupa perbukitan dan pegunungan. Survei lapangan dilakukan pada 9 kecamatan dengan menggunakan GPS (Global Positioning System). Survei dilakukan dengan mempertimbangkan visual line of sight dengan bantuan dari masyarakat setempat melalui metode wawancara.

Permasalahan pokoknya, bagaimana melalui survei lapangan diperoleh 9 titik point sebagai kandidat penempatan peralatan jaringan dengan sekali hop tanpa repeater. Radius fresnel zone merupakan hal yang diperhatikan pada ketersambungan antar kecamatan di kabupaten Ngada, dengan topologi partial mesh yang memberikan manfaat dari topologi mesh dan memiliki jalur backup.
\end{abstract}

Kata Kunci : Site Survei, Wireless, Line of Sight, GPS.

\section{Pendahuluan}

Pada pendahuluan berisi tentang latar belakang, rumusan masalah, batasan masalah dan metode penelitian yang dijabarkan dibawah ini :

\footnotetext{
${ }^{1}$ Teknik Informatika, Fakultas Teknologi Informasi,Universitas Kristen Duta Wacana

${ }^{2}$ Teknik Informatika, Fakultas Teknologi Informasi Univeristas Kristen Duta Wacana

${ }^{3}$ Teknik Informatika, Fakultas Teknologi Informasi,Universitas Kristen Duta Wacana
} 


\subsection{Latar Belakang :}

Teknologi informasi dan komunikasi data memungkinkan penyampaian informasi dapat diperoleh lebih cepat. Hal ini disadari oleh aparat pemerintahan yang peka terhadap perkembangan teknologi informasi dengan memulai program e-Government. e-Government jika dikembangkan dan dikelola dengan tepat dapat memberikan dampak positif bagi peningkatan pelayanan publik dan kinerja pemerintahan.

Blueprint merupakan landasan e-Government sebelum tahapan implementasi dilaksanakan, sehingga pihak-pihak terkait perlu menyamakan persepsi melalui blueprint yang dibuat. Blueprint menjadi penting karena investasi di bidang teknologi informasi cukup mahal dan pemerintah tidak boleh gegabah dalam melakukan investasi di bidang teknologi informasi.

Pemerintahan Kabupaten Ngada saat ini telah memiliki blueprint e-Government, permasalahannya bahwa pemerintahan belum memiliki blueprint infrastruktur jaringan yang menjadi fondasi bagi investasi di bidang teknologi informasi khususnya membangun sarana komunikasi antar kecamatan pada kabupaten Ngada. Hal ini menjadi alasan utama dilakukan penelitian untuk melakukan 'Perancangan Blueprint Infrastruktur Jaringan Backbone Kabupaten Ngada'.

\subsection{Rumusan Masalah}

Masalah yang akan dijadikan fokus penelitian dalam karya ilmiah ini adalah :

a. Menentukan titik-titik lokasi jalur backbone bagi ketersambungan antar kecamatan pada kabupaten Ngada.

b. Membuat dan merancang topologi partia mesh untuk ketersambungan backbone kecamatankecamatan pada kabupaten Ngada.

c. Menganalisis tipografi kabupaten Ngada guna mendapatkan tinggi tower.

d. Menentukan piranti untuk infrastruktur jaringan pada kabupaten Ngada.

e. Hasil akhir blueprint infrastruktur pada kabupaten Ngada.

\subsection{Batasan Masalah}

Permasalahan dalam penelitian ini dibatasi oleh beberapa hal sebagai berikut:

a. Menentukan koordinat titik-titik lokasi di 9 Kecamatan pada Kabupaten Ngada.

b. Koneksi antar kesamatan menggunakan teknologi wireless, dimana jalur backbone menggunakan topologi jaringan partial mesh.

c. Penentuan ketinggian tower sesuai kondisi lokasi hasil survei lapangan. 


\section{Landasan Teori}

Beberapa dasar teori yang menjadi landasan penulisan karya ilmiah ini, yaitu :

\subsection{Konsep Dasar Fisika Radio}

Komunikasi wireless (nirkabel) menggunakan gelombang elektromagnet untuk mengirimkan sinyal jarak jauh. Sebuah gelombang mempunyai kecepatan, frekuensi dan panjang gelombang. Rumus untuk menghitung panjang gelombang adalah :

Kecepatan $=$ Frekuensi ${ }^{*}$ Panjang Gelombang

Keterangan :

- Kecepatan memiliki satuan m/s dan memakai kecepatan cahaya yaitu $3.10^{8} \mathrm{~m} / \mathrm{s}$.

- Frekuensi memiliki satuan Hertz.

- Panjang gelombang ( $\lambda$ / lambda) memiliki satuan meter.

Panjang gelombang adalah jarak yang di ukur dari satu titik sebuah gelombang ke titik yang sama pada gelombang berikutnya. Frekuensi adalah jumlah dari gelombang yang melalui titik tertentu dalam sebuah periode waktu. Gelombang memiliki sebuah parameter yang disebut amplitudo. Amplitudo adalah jarak dari pusat gelombang ke puncak tertinggi gelombang.

\subsection{Perilaku Gelombang Radio}

Beberapa aturan dalam gelombang yaitu :

a. Semakin panjang suatu panjang gelombang, semakin jauh gelombang itu merambat.

Untuk penggunaan daya yang sama, panjang gelombang yang lebih panjang cenderung akan merambat lebih jauh dibandingkan dengan panjang gelombang yang lebih pendek. Misalnya, pada radio FM pemancar pada wilayah $88 \mathrm{Mhz}$ dengan yang berada pada wilayah $108 \mathrm{Mhz}$ pada daya yang sama, frekuensi $88 \mathrm{Mhz}$ dapat mencapai jarak yang lebih jauh dibandingkan frekuensi $108 \mathrm{Mhz}$.

b. Semakin panjang suatu panjang gelombang, semakin mudah gelombang melalui atau mengitari penghalang.

Semakin panjang suatu panjang gelombang, jika terdapat penghalang yang besarnya tidak melebihi panjang gelombang itu, maka yang terjadi adalah gelombang itu tidak akan musnah atau hilang akibat penghalang. Hal ini dapat dibuktikan pada gelombang air jika 
penghalang yang ada tidak melebihi panjang gelombang air tersebut, maka penghalang itu akan terbawa gelombang air, hal yang sama juga terjadi untuk gelombang elektromagnetik. Oleh karena itu, jika dilakukan perbandingan antara gelombang 2,4 Ghz dengan $5 \mathrm{Ghz}$, maka 2,4 Ghz akan jauh lebih baik untuk menembus penghalang yang ada tetapi juga harus disesuaikan dengan panjang gelombang 2,4 Ghz.

c. Semakin pendek suatu panjang gelombang, semakin banyak data yang dikirimkan.

Hal ini dapat dibuktikan dengan kerapatan gelombang, untuk gelombang 2,4 Ghz dan 5 Ghz memiliki kerapatan yang berbeda, semakin rapat gelombang semakin banyak getaran yang dihasilkan mengakibatkan semakin banyak data yang dibawa atau dialirkan. Hal ini memang konsekuensi jika menggunakan gelombang 2,4 Ghz sebagai aliran paket data pada wireless.

\subsection{Line of sight}

Line of sight dapat diartikan sebagai kondisi tampak pandang antara tower pengirim dan penerima tanpa adanya obyek penghalang (obstacle). Istilah Line of Sight, dimodelkan sebagai melihat titik B dari titik A dimana tidak terdapat penghalang antara A dan B, sehingga disebut Line of Sight. Konsep Line of Sight menjadi lebih kompleks jika menggunakan gelombang mikro, dimana sebagian besar karakteristik perambatan atau propagasi gelombang elektromagnetik tergantung pada panjang gelombangnya.

Panjang gelombang cahaya adalah sekitar 0.5 mikrometer, sementara gelombang mikro yang biasa digunakan dalam jaringan wireless mempunyai panjang gelombang beberapa sentimeter. Hal ini menjadikan pancaran gelombang mikro akan lebih lebar, dimana gelombang mikro membutuhkan ruang atau jalan yang lebih lebar.

Pada ketersambungan line of sight A dan B terdapat daerah Fresnel yang merupakan area dimana sinyal dari antena tower terdistribusi secara efektif. Daerah Fresnel harus bersih dari segala obstacle.

\subsection{Teknik Site Survei}

Site survey adalah teknik melakukan survei kondisi sebuah tempat untuk menyiapkan sebuah site untuk instalasi peralatan radio (Purbo, 2005). Beberapa peralatan untuk melakukan site survey adalah :
a. Hand-held GPS atau kompas.
b. Peta tipografi.
c. Altimeter atau pengukur ketinggian. Hal ini kadang tidak dibutuhkan apabila GPS yang dimiliki telah mendukung.




\section{Hasil dan Pembahasan}

\subsection{Metoda Penelitian}

Survei lapangan dilakukan karena topografi wilayah Ngada yang berbukit-bukit. Survei akan mendapatkan titik lokasi yang dibutuhkan untuk membangun tower komunikasi setiap kecamatan di kabupaten Ngada. Survei lapangan dilakukan di 9 kecamatan dengan tahapan awal sebagai berikut :

a.) Menelaah keadaan geografis wilayah kabupaten Ngada melalui sumber ngadakab.go.id sebelum melakukan survei lapangan.

b.) Melakukan study map menggunakan google earth dan google map untuk mempelajari lokasi dan ketinggian wilayah kabupaten Ngada sebagai pengganti peta tipografi yang kurang memadai.

c.) Meminta ijin instansi pemerintah terkait, yaitu ijin memasuki wilayah kabupaten Ngada.

d.) Memasukkan surat ijin pada kantor camat untuk 9 kecamatan yang terdapat pada kabupaten Ngada.

e.) Melakukan wawancara dengan masyarakat setempat mengenai wilayah kabupaten Ngada, yang meliputi area coverage untuk mendapatkan Line Of Sight terhadap kecamatankecamatan yang terdapat di kabupaten Ngada.

f.) Perencanaan awal titik-titik lokasi hasil wawancara dengan masyarakat setempat.

g.) Penentuan topologi jaringan backbone yang akan digunakan.

h.) Melakukan survei lapangan.

i.) Melakukan perhitungan line of sight, Fresnel zone, eirp, fsl (link budget).

j.) Topologi akhir jaringan backbone untuk infrastruktur jaringan kabupaten Ngada.

\subsection{Tipografi Wilayah}

Kabupaten Ngada merupakan salah satu kabupaten di pulau Flores dengan topogafi wilayah berbukit-bukit. Hal ini dapat menguntungkan tetapi juga dapat merugikan bagi ketersambungan antar kecamatan pada kabupaten Ngada. Bukit-bukit dapat memblokir sinyal yang dikirim dari pengirim (transceiver) menuju penerima (receiver), tetapi jika terdapat listrik pada bukit tersebut akan menjadikan tempat yang baik bagi penempatan repeater.

Repeater merupakan node yang dikonfigurasi untuk mengirimkan trafik (transmisi data) yang tidak diperuntukkan untuk node itu sendiri tetapi diperuntukkan bagi node lain, dimana repeater berguna untuk memperpanjang jangkauan sinyal pembawa data. Kondisi ini tentunya memerlukan penanganan khusus dalam membangun koneksi antar kecamatan pada kabupaten Ngada. 
Survei lapangan menjadi pilihan penulis dalam mengatasi topografi kabupaten Ngada yang sebagian wilayahnya terdiri dari perbukitan. Survei dibutuhkan untuk penentuan lokasi yang tepat membangun tower komunikasi, penempatan antena agar koneksi stabil dan aman. Stabil maksudnya adalah koneksi yang dibangun minim terjadi pemutusan koneksi antar node kecamatan, sedangkan aman dalam hal gangguan berupa cuaca hujan maupun petir yang sering menjadi pemicu putusnya koneksi pada node yang terkena sambaran petir. Selain itu, dipastikan keamanan dari sisi koneksi dengan memasukkan tingkat keamanan dari probe dan virus pada sisi komputer server sehingga data dipastikan sampai pada sisi cliet tanpa disusupi hacker maupun cracker.

\subsection{Analisis Kebutuhan}

Berdasarkan penjelasan permasalahan pada analisis masalah, maka harapannya data dan informasi tiap kecamatan menjadi lebih cepat diproses dengan tepat sasaran, mengurangi biaya anggaran pemerintah, menaikkan minat investor dan terjadinya transparansi bidang keuangan. Maka dengan ini, diperlukan jalur koneksi jaringan antar kecamatan dengan pemerintah kabupaten. Pada penelitian karya ilmiah ini, penulis akan menitik beratkan pada penentuan backbone jaringan antar kecamatan pada kabupaten Ngada, dimana saat ini belum terdapat koneksi intranet yang memadai antar kecamatan dan koneksi kecamatan dengan pemerintah kabupaten.

Pembangunan jaringan induk (backbone) menjadi infrastruktur penting suatu jaringan skala besar, dimana jaringan tersebut menjadi penopang utama berfungsinya jaringan lain yang ada. Bila backbone mengalami kerusakan bahkan terjadi pemutusan koneksi pada salah satu node maka akan terjadi kemungkinan pelayanan koneksi client terputus. Pemilihan perangkat backbone yang tepat menjadi sangat penting.

Hal-hal yang menjadi perhatian utama agar dapat menghubungkan kecamatankecamatan dengan kabupaten Ngada diperlukan beberapa hal di bawah ini :

\section{a. Topologi}

Topologi merupakan aspek penting dalam membangun suatu koneksi, topologi jaringan adalah suatu cara atau bentuk yang digunakan untuk menghubungkan sutu node dengan node lain sehingga membentuk sebuah jaringan. Pada penelitian karya ilmiah ini penulis menggunakan topologi partial mesh untuk membangun ketersambungan antar kecamatan dengan kabupaten Ngada. Jenis topologi partial mesh merupakan topologi jaringan dimana beberapa nodes dari jaringan terhubung lebih dari satu nodes dengan koneksi point-to-point. Pada topologi ini hanya beberapa node yang terhubung langsung dengan node lainnya, dalam arti hanya beberapa 
kecamatan yang terhubung langsung dengan kecamatan lainnya, sedangkan kecamatan lain tidak terhubung secara langsung. Hal tersebut memungkinkan user mengambil manfaat yang diberikan topologi full mesh tanpa biaya dan kompleksitas yang diperlukan untuk sebuah koneksi antar node dalam jaringan.

\section{b. Tower komunikasi}

Membangun tower komunikasi merupakan fondasi awal untuk dapat menghubungkan kecamatan-kecamatan pada kabupaten Ngada. Untuk dapat membangun tower, diperlukan informasi lokasi dengan berbagai pertimbangan untuk menentukan letak posisi tower komunikasi yang akan dibangun.

\section{c. Penempatan antena}

Setelah lokasi pembangunan tower diketahui maka penempatan antena yang tepat diperlukan untuk dapat menglingkuti (meng-cover) area publik seperti sekolah dan tempat wisata pada tiap kecamatan di kabupaten Ngada, terkhusus pada instansi maupun kantor dinas terkait. Selain itu, diperlukan pemilihan antena yang tepat dalam memenuhi kebutuhan masyarakat dan pemerintah. Pemilihan antena didasarkan pada beberapa pertimbangan, yaitu: jarak antar unit wireless, sesuai kebutuhan tipe koneksi (point-to-point atau point-to-multipoint), serta kondisi wilayah/lapangan yang ada.

\section{d. Pemilihan unit wireless}

Faktor-faktor yang menjadi pertimbangan adalah :

- Faktor biaya

Faktor ini biasaya dijadikan acuan pertama kali dengan adanya anggapan bahwa semakin murah produk maka kualitas dan fitur semakin terbatas.

- Kualitas

Ini terkait dengan prinsip bahwa sesuatu dengan kualitas baik akan berbanding lurus dengan performance di lapangan.

- Jarak jangkauan

Jarak wireless berbanding lurus dengan daya unit radio dan unit amplifier atau biasa disebut dengan unit booster yang berfungsi memperkuat sinyal, yang akan berdampak memperpanjang jangkauan. 
Jaringan intranet merupakan jaringan komputer internal di lingkungan kabupaten Ngada dengan memanfaatkan teknologi WEB. Infrastruktur yang dibangun menggunakan kombinasi jaringan broadband wireless access (BWA) dan Jaringan kabel tembaga yang memanfaatkan proyek pemerintah dalam hal ini Palapa Ring Timur yang saat ini penggaliannya telah sampai pada Mataloko.

BWA dipergunakan untuk mengkoneksikan seluruh kecamatan di kabupaten Ngada. Smartbridges Broadband Wireless Access dipilih penulis karena telah diimplementasikan pada beberapa negara seperti Nigeria, Afrika selatan, Irak, Saudi arabia, Mesir, India dan Indonesia. Selain itu mendukung penggunaan standar wireless IEEE $802.11 \mathrm{a} / \mathrm{b} / \mathrm{g}$ dengan jangkauan akses sampai $40 \mathrm{~km}$.

\subsection{Analisis Bandwidth}

Bandwidth diukur berdasarkan jumlah bit yang dikirim media dalam sebuah interval waktu. Definisi Bandwidth adalah banyaknya ukuran suatu data atau informasi yang dapat mengalir dari suatu tempat ke tempat lain dalam sebuah jaringan di waktu tertentu. Bandwidth dapat dipakai untuk mengukur baik aliran data analog maupun data digital. Pada jangka waktu tertentu, bandwidth dibatasi dalam kondisis client yang melakukan download dan upload dengan kapasitas yang tinggi sehingga client lain mengalami koneksi yang melambat. Untuk alasan ini, bandwidth harus dikelola dan diprioritaskan seperti sumber daya terbatas lainnya. Throughput dapat dimaksimalkan dengan mengurangi lalu lintas yang tidak diinginkan dari jaringan.

Bandwith dibagi menjadi dua jenis yaitu :

a. Up Stream adalah bandwith yang digunakan untuk mengirim data (misalnya mengirim file melalui Ftp ke salah satu alamat jaringan).

b. Down Stream adalah Bandwith yang digunakan untuk menerima data (misalnya menerima file atau data dari satu alamat jaringan).

Beberapa faktor yang dapat mempengaruhi kecepatan transfer data :

a. Spesifikasi komputer client dan server.

b. Peralatan jaringan.

c. Topologi jaringan.

d. Jenis data yang ditransfer.

e. Jumlah user yang aktif di jaringan.

Intranet adalah jaringan yang menghubungkan internal perusahaan/kantor yang dapat diakses oleh pegawainya. Pengembangan infrastruktur intranet dapat dipergunakan untuk 
sistem aplikasi yang berbasis web, di mana pengguna menggunakan browser pada komputer masing-masing (yang terhubung dengan network), untuk menggunakan aplikasi-aplikasi yang berbasis transaksi dalam intranet. Hal ini menyebabkan spesifikasi komputer yang digunakan tidaklah perlu terlalu tinggi, serta secara teknis lebih mempermudah pengembangan aplikasi dan memberikan efisiensi penggunaan bandwidth.

\section{Analisis}

\subsection{Desain Topologi}

Topologi yang dipilih penulis merupakan desain topologi partial mesh dimana topologi ini memberikan manfaat biaya yang lebih murah. Topologi ini dipilih dengan alasan sebagai berikut :

a. Memiliki sistem redundancy

Topologi ini menggunakan sistem koneksi cadangan. Hal ini berfungsi ketika koneksi down maka dapat menggunakan rute lain.

b. Mengaplikasikan manfaat topologi mesh yang merupakan kombinasi keuntungan topologi ring dan star, yaitu biaya implementasi lebih murah.

c. Topologi partial mesh yang merupakan bagian dari topologi mesh sangat cocok untuk wilayah pegunungan dan berbukit-bukit yang memiliki masalah pada line of sight.

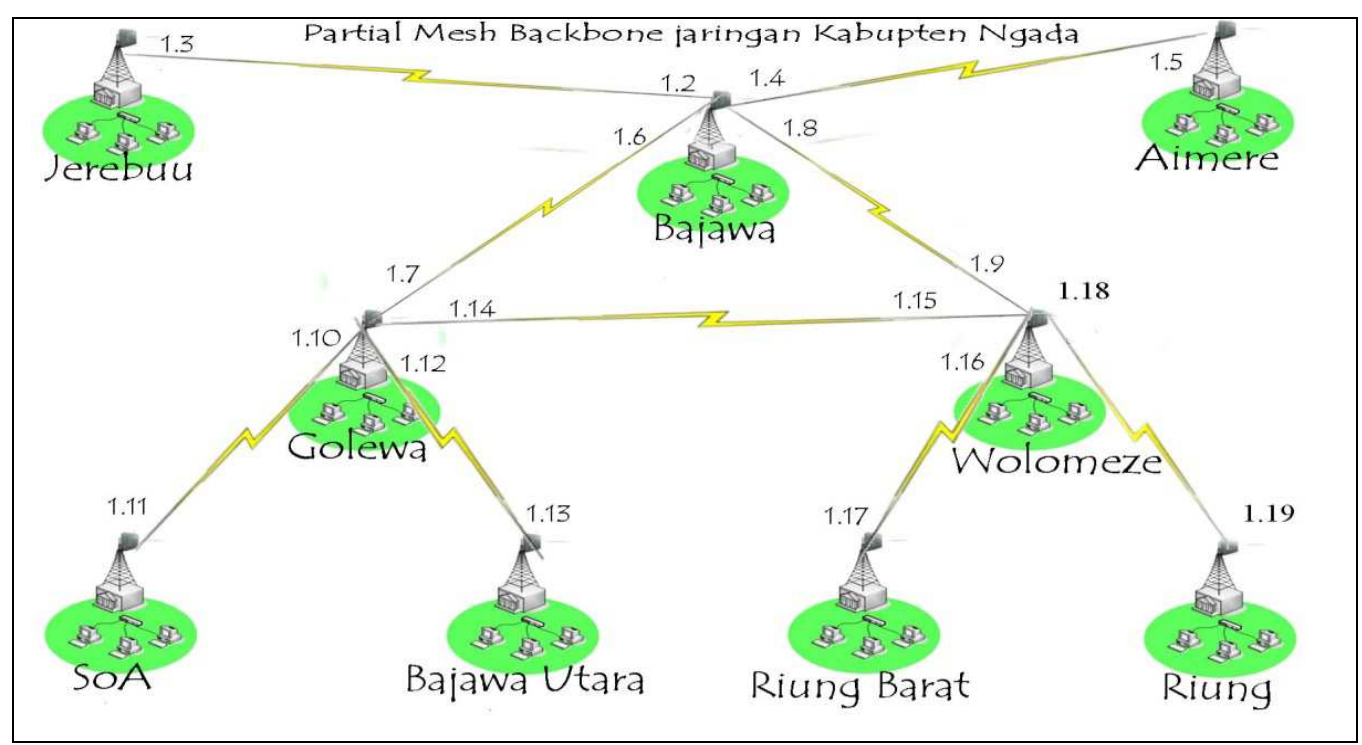

Gambar 1. Topologi partial mesh Kabupaten Ngada

Gambar 1 menampilkan topologi partial mesh kabupaten Ngada sebagai hasil akhir pengamatan lapangan untuk menentukan posisi tambahan, yaitu ketersambungan kecamatan 
Wolomeze menuju Riung penulis memilih repeater, karena belum memperoleh daerah pada kecamatan Riung yang memiliki line of sight terhadap kecamatan Wolomeze.

Berdasarkan hasil wawancara dengan masyarakat setempat, Penulis kemudian melakukan pendakian pada bukit Rawuk untuk melakukan pengamatan lapangan. Berdasarkan pengamatan ini, maka Bukit tersebut dipilih penulis sebagai lokasi yang memiliki hoop sekali terhadap ketersambungan kecamatan Wolomeze menuju Riung.

\subsection{Desain Konstruksi Tower}

Tower merupakan sarana penempatan antena yang dapat membantu dalam membangun ketersambungan satu node dengan node yang lainnya. Antena berfungsi mengirimkan sinyal dari transmitter menuju receiver sehingga terjadi komunikasi. Membangun tower perlu mempertimbangkan beberapa hal di bawah ini :

a. Tinggi tower

Tinggi tower menentukan kualitas sinyal terhadap ketersambungan.

b. Beban angin dan beban antena

Angin merupakan masa udara yang bergerak, angin dapat bergerak secara horizontal maupun vertikal dengan kecepatan yang bervariasi. Faktor pendorong bergeraknya masa udara adalah perbedaan tekanan udara antara satu tempat dengan tempat lain. Angin dapat menjadi ancaman bangunan konstruksi yang tinggi, karena semakin tinggi bangunan konstruksi maka akan semakin besar kecepatan angin yang diterima sehingga rentan terhadap kerusakan.

Beban angin yang bekerja terdiri dari beban pada struktur menara dan beban pada antena. Beban angin yang bekerja pada antena biasanya tergantung dari jenis antena yang digunakan dan ukuran diameter antena. Beban angin yang diterima antena akan semakin besar jika diameter antena yang digunakan juga semakin besar.

Angin dapat mempengaruhi sistem wireless, ketika kekuatan angin menabrak antena, tower maupun tiang akan mempengaruhi arah dan posisi antena. Adanya kekuatan angin dapat menyebabkan beberapa hal berikut :

- Arah antena dapat berubah karena antena berputar

- Menara, antena yang tidak dirancang dengan baik untuk menghadapi kekuatan angin dapat patah atau rusak akibat kekuatan angin ini.

c. Mutu baja yang digunakan

Rangka baja untuk membangun tower menjadi faktor yang dipertimbangkan agar dapat menahan beban antena dan beban angin. Sehingga dalam mendesain konstruksi tower, penulis 
menawarkan menggunakan tower kaki tiga. Tower kaki tiga disarankan untuk memakai besi dengan diameter $2 \mathrm{~cm}$ ke atas.

Alasan pemilihan tower ini, karena ketinggian maksimal tower bisa direkomendasi sampai 60 meter dengan ketinggian rata-rata adalah 40 meter. Tower jenis ini disusun atas beberapa stack (potongan), pilihan tinggi 1 stack yaitu 4 meter atau 5 meter. Makin pendek stack maka makin kokoh, namun biaya pembuatannya semakin mahal, karena setiap stack membutuhkan tali pancang atau spanner. Jarak patok spanner dengan tower minimal 8 meter. Makin panjang makin baik, karena ikatannya makin kokoh, sehingga tali penguat tersebut tidak makin meruncing di tower bagian atas.

\section{Kesimpulan}

Ketersambungan koneksi backbone kabupaten Ngada dapat diperoleh posisi lokasi 9 titik point untuk membentuk ketersambungan di 9 kecamatan, dengan keuntungan bahwa jarak antar titik point tidak lebih dari $35 \mathrm{~km}$ dan tanpa menggunakan repeater sebagai penguat sinyal.

Penunjang ketersambungan antar kecamatan mengunakan topologi partial mesh untuk jalur backbone. Topologi partial mesh yang merupakan bagian dari topologi mesh yang cocok untuk wilayah pegunungan dan berbukit-bukit yang memiliki masalah pada line of sight.

Pilihan tower disarankan menggunakan tower kaki tiga, dengan spesifikasi stack yang memiliki panjang 4 atau 5 meter dan menggunakan rangka baja, sehingga memiliki keamanan dan kekuatan untuk menopang antenna wireless dari gangguan angin maupun cuaca.

Berdasarkan hasil keseluruhan penelitian lapangan dan wawancara, maka topologi Gambar 1 merupakan penggambaran topologi parsial mesh dan akan dijadikan sebagai blueprint pemasangan tower antenna wireless di Kabupaten Ngada.

\section{Daftar Pustaka}

Aggelou, George.(2004). Wireless Mesh Networking ,Mcgraw-Hill : communication

Graziani, Rick. (2003). Antennas-part 1 Antenna characteristic and Line of Sight Paths

Graziani, Rick.(2005).Wireless Radio Technology

Purbo,W.Onno.(2005). Buku Pegangan Internet Wireless dan Hotspot. Penerbit: PT Elex Media Komputindo kelompok Gramedia,Jakarta

Syamsudin M.(2010). Cara cepat belajar infrastruktur jaringan wireless.Penerbit :

GAVA MEDIA

Wowok.(200). Antena wireless untuk rakiyat. Penerbit : ANDI 